\title{
Analisis Kendala Orang Tua dalam Mendampingi Anak Belajar di Rumah Pada Masa Pandemi Covid-19
}

\author{
Anita Wardani ${ }^{1}{ }^{凶}$, Yulia Ayriza ${ }^{2}$ \\ Pendidikan Anak Usia Dini, Universitas Negeri Yogyakarta ${ }^{1}$ \\ Bimbingan dan Konseling, Universitas Negeri Yogyakarta² \\ DOI: $10.31004 /$ obsesi.v5i1.705
}

\begin{abstract}
Abstrak
Artikel ini bertujuan untuk mengetahui kendala- kendala apa saja yang dialami oleh orang tua selama mendampingi anak belajar dirumah pada masa pandemi Covid-19. Metode yang digunakan dalam penelitian ini adalah studi kasus melalui wawancara dengan analisis tematik pada 12 orang tua dengan anak yang sedang bersekolah di taman kanak-kanak. Hasil penelitian ini menunjukkan bahwa secara umum kendala- kendala orang tua dalam mendampingi anak belajar di rumah pada masa pandemi Covid- 19 adalah kurangnya pemahaman materi oleh orang tua, kesulitan orang tua dalam menumbuhkan minat belajar anak, tidak memiliki cukup waktu untuk mendampingi anak karena harus bekerja, orang tua tidak sabar dalam mendampingi anak saat belajar dirumah, kesulitan orang tua dalam mengoperasikan gadget, dan kendala terkait jangkauan layanan internet. Penelitian ini diharapkan mampu menggali kendala- kendala orang tua dalam mendampingi anak ketika belajar dirumah sehingga penelitian ini mampu berkontribusi terhadap penelitian selanjutnya dalam menggali solusi untuk masalah- masalah tersebut.
\end{abstract}

Kata Kunci: kendala orang tua; anak, belajar dirumah; masa pandemi.

\begin{abstract}
This article aims to find out what obstacles are experienced by parents while accompanying children to study at home during the Covid-19 pandemic. The method used in this research is a case study through interviews with thematic analysis of 12 parents who have children who are attending kindergarten. The results of this study indicate that in general the constraints of parents in assisting children to learn at home during the Covid-19 pandemic are the lack of understanding of the material by parents, the difficulty of parents in growing children's learning interest, not having enough time to accompany children because they have to work, parents are impatient in accompanying children when studying at home, parents' difficulties in operating gadgets, and obstacles related to the reach of internet services. This research is expected to be able to explore the constraints of parents in assisting children when studying at home so that this research is able to contribute to further research in exploring solutions to these problems.
\end{abstract}

Keywords: constraints of parents; children, study at home; pandemic period.

Copyright (c) 2020 Anita Wardani, Yulia Ayriza

$\triangle$ Corresponding author:

Email Address : aneeta.wayway@gmail.com (Yogyakarta, Indonesia)

Received 31 May 2020, Accepted 4 August 2020, Published 18 August 2020

772 | Jurnal Obsesi : Jurnal Pendidikan Anak Usia Dini, 5(1), 2021 


\section{PENDAHULUAN}

Tidak lama ini dunia sedang diguncang dengan adanya virus corona atau yang sekarang disebut dengan Covid- 19 (Corona Virus Desease). Disebutkan bahwa virus ini pertama kali berasal dari kota Wuhan, China sejak Desember 2019 (Lee, 2020). Data terkini menunjukkan bahwa jumlah pasien positif pada 216 negara diseluruh dunia hingga bulan Agustus 2020 telah mencapai lebih dari 18 juta pasien dengan penambahan 171.815 orang telah dinyatakan positf dalam 24 jam. Negara Indonesia pun tak luput dari paparan Covid19. Bahkan Indonesia menjadi negara dengan jumlah akumulasi paparan Covid-19 tertinggi di Asia Tenggara, yaitu mencapai 113.134 sampai dengan bulan Agustus 2020 (pikiranrakyat.com)

Pemerintah di Indonesia menanamkan kebijakan untuk menyikapi permasalahan ini dengan memberlakukan social distancing kepada seluruh lapisan masyarakat. Bukan hanya itu, PSBB (Pembatasan Sosial Berskala Besar) juga diberlakukan dibeberapa kota besar di Indonesia, misalnya kota Jakartaa, dan kebijakan ini telah tertuang dalam PP Nomor 21 Tahun 2020. Kebijakan tersebut diberlakukan guna memutus mata rantai penyebaran Covid19. Hal ini ternyata berdampak pada berbagai aktivitas termasuk diantaranya aktivitas belajar mengajar. Pemerintah telah menetapkan kebijakan belajar dari rumah atau biasa disingkat BDR melalui Surat Edaran Mendikbud Nomor 36962/MPK.A/HK/2020 yang berisikan bahwa pembelajaran harus dilakukan secara daring supaya Corona Virus Desease (Covid-19) dapat dicegah penyebarannya. (Karnawati \& Mardiharto, 2020)

Pembelajaran daring yang ditetapkan pemerintah, ditujukan kepada seluruh jenjang pendidikan dari TK hingga perguruan tinggi. Dipilihnya alternatif ini dikarenakan berkembangnya revolusi industri 4.0. Berkembangnya revolusi industri sangat mendukung terlaksananya pembelajaran daring dari rumah, karena pembelajaran daring adalah pembelajaran yang mengeliminasi waktu dan jarak dengan bantuan platform digital berbasis internet yang mampu menunjang pembelajaran untuk dilakukan tanpa adanya interaksi fisik antara pendidik dan peserta didik (Putra \& Irwansyah, 2020), sehingga kecanggihan teknologi jaman sekarang diharapkan mampu menunjang kegiatan daring tersebut. Namun pada jenjang pendidikan TK, pembelajaran daring memerlukan keterlibatan orang tua langsung dalam pelaksanaannya.

Selama pandemi Covid-19 berlangsung, pembelajaran secara daring telah dilakukan hampir diseluruh penjuru dunia, namun sejauh ini pembelajaran dengan sistem daring belum pernah dilakukan secara serentak (Sun et al., 2020). Sehingga dalam proses pembelajaran yang dilakukan secara daring ini, semua elemen pendidikan diminta untuk mampu dalam memberikan fasilitas- fasilitas pembelajaran agar tetap aktif walaupun dilakukan tanpa tatap muka secara langsung. Orang tua dituntut mampu membimbing anak belajar dari rumah dan mampu menggantikan guru disekolah, sehingga peran orang tua dalam tercapainya tujuan pembelajaran daring dan membimbing anak selama belajar dirumah menjadi sangat penting.

Dengan adanya kebijakan pemerintah untuk belajar dirumah secara daring, maka peran yang biasanya dilaksanakan oleh satuan pendidikan, sekarang telah berganti fungsi di satuan keluarga. Artinya saat ini rumah menjadi pusat kegiatan bagi semua anggota keluarga. Hal ini bisa jadi berdampak positif, karena pusat kegiatan kembali keasalnya, yaitu rumah. Akan tetapi jika semua kegiatan hanya dilakukan dirumah saja, hal juga akan bisa menimbulkan Psikosomatis, yaitu gangguan fisik yang disebabkan oleh faktor kejiwaan dan tumpukan emosi yang dapat menimbulkan guncangan dalam diri seseorang dimasyarakat, seperti kecemasan, stress, lingkungan sosial yang banyak mempengaruhi pikiran negatif, seperti karena berita hoax dan lain sebagainnya (Sari et al., 2021).

Kondisi dilapangan saat ini menunjukkan bahwa pembelajaran daring, atau pembelajaran yang dilakukan dirumah dengan bimbingan orang tua pada anak usia dini memiliki beberapa kendala, sehingga tidak sedikit orang tua yang meminta pihak sekolah untuk dapat dengan segera melaksanakan pembelajaran secara tatap muka. Kendala- 
kendala yang dialami orang tua dalam mendampingi anak belajar dirumah meliputi kurangnya pemahaman materi oleh orang tua, kesulitan orang tua dalam menumbuhkan minat belajar anak, tidak memiliki cukup waktu untuk mendampingi anak karena harus bekerja, orang tua tidak sabar dalam mendampingi anak saat belajar dirumah, kesulitan orang tua dalam mengoperasikan gadget, dan kendala terkait jangkauan layanan internet. Oleh karena itu, dalam pelaksanaan daring ini ternyata orang tua memiliki banyak kendala dalam mendampingi anak belajar dirumah.

Analisis kendala orang tua dalam mendampingi anak belajar dirumah yang dilakukan oleh para peneliti sangat banyak ketika sebelum adanya pandemi Covid-19, seperti penelitian yang dilakukan oleh Saesti, yang menyatakan bahwa keterlibatan pendampingan orang tua terhadap pembelajaran anak lebih banyak dilakukan dengan guru disekolah, misalnya kegiatan outing class, mini trip, dan market day (Prabhawani, 2016) sehingga kendala orang tua dalam mendampingi anak belajar tidak secara khusus diteliti saat orang tua dan anak berada dirumah, oleh karena itu analisis kendala orang tua dalam mendampingi anak belajar dirumah selama adanya pandemi Covid-19 masih belum banyak dilakukan, walaupun memang sudah ada penelitian mengenai kendala orang tua dalam mendampingi anak belajar dirumah pada masa pandemi Covid-19 seperti ada orang tua yang memberlakukan gadget sebagai sahabat anak ketika anak merasa bosan, kurangnya intervensi orang tua pada dunia anak, masalah orang tua dalam menghadapi anak dan juga kejenuhan orang tua dan anak selama masa pandemi ini (Rohayani, 2020), namun penelitian ini berfokus kepada orang tua anak usia sekolah dasar, bukan secara khusus berfokus kepada orang tua anak dengan usia TK.

Berdasarkan hal tersebut kajian dalam penelitian ini menjadi sangat penting untuk dilakukan dalam memahami bagaimana sebenarnya kendala yang dialami orang tua dalam mendampingi anaknya belajar dirumah menggantikan peran guru saat terjadi pandemi Covid-19 dengan metode pembelajaran daring serta bagaimana penanganan atas kendalakendala yang dialami orang tua dalam mendampingi anak belajar dirumah dimasa pandemi Covid-19.

\section{METODOLOGI}

Metode penelitian yang digunakan dalam penelitian ini adalah kualitatif deskriptif. Penelitian kualitiatif deskriptif adalah berupa penelitian dengan metode atau pendekatan studi kasus (case study). Penelitian ini memusatkan diri secara insentif pada satu obyek tertentu yang mempelajarinya sebagai suatu kasus. Data dari studi kasus dapat diperoleh dari semua pihak yang bersangkutan, dengan kata lain dalam studi ini data dikumpulkan dari berbagai sumber (Nawawi, 2003). Studi kasus sangat sesuai untuk menjawab pertanyaan "bagaimana" karena jenis pertanyaan seperti ini mampu menggali data lebih dalam (Yin, 2003). Dalam hal ini peneliti menganalisis kendala yang yang dialami oleh orang tua dalam mendampingi anak belajar dirumah selama pandemi Covid-19 terjadi. Subyek dalam penelitian ini adalah orang tua yang memiliki anak usia dini yang bersekolah di TK dengan jumlah 12 orang (12 ibu).

Alasan pemilihan subyek pada penelitian ini dilatar belakangi oleh keharusan para subyek untuk mendampingi anak belajar dirumah pada masa pandemi. Subyek yang dipilih minimal 2 bulan lamanya telah mendampingi anak belajar dirumah dimasa pandemi Covid19. Teknik pengumpulan data yang digunakan adalah wawancara dan data dianalisis dengan menggunakan tematik, yaitu teknik analisis yang menekankan pada penyusunan koding dengan mengacu pada pertanyaan penelitian yang telah ditetapkan, sehingga tematema yang tersusun sesuai dengan pertanyaan penelitian tersebut dan menjadi acuan dalam memaparkan fenomena yang terjadi (Heriyanto, 2018). 


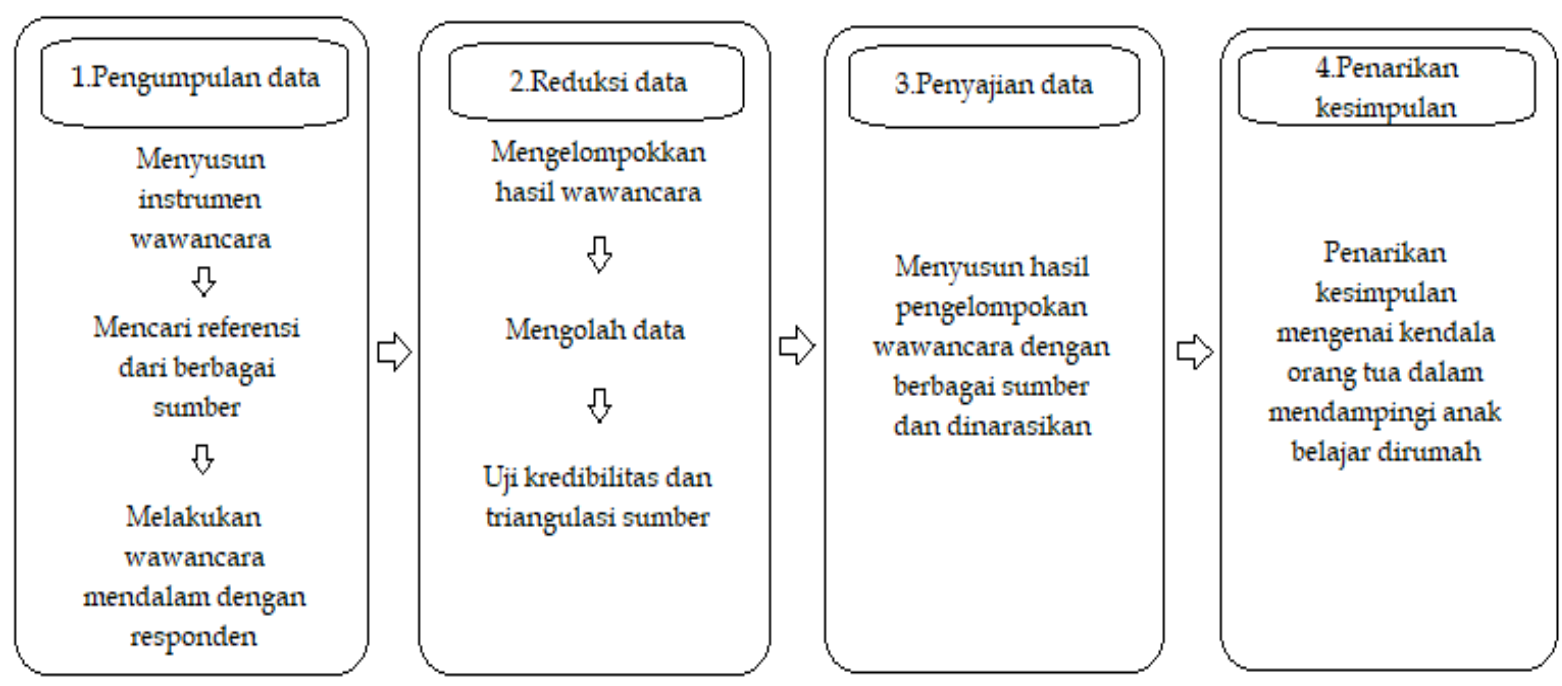

Tabel 1. Langkah-langkah penelitian (Satrianingrum et al., 2021)

\section{HASIL DAN PEMBAHASAN}

Peristiwa Covid-19 yang terjadi hampir diseluruh belahan dunia ini menunjukkan bahwa semakin pentingnya peran orang tua dalam membimbing anak belajar dirumah menggantikan tugas guru disekolah. Hal ini tentu saja menimbulkan masalah atau kendala baru yang dialami orang tua, seperti kurangnya pemahaman materi oleh orang tua, kesulitan orang tua dalam menumbuhkan minat belajar anak, tidak memiliki cukup waktu untuk mendampingi anak karena harus bekerja, orang tua tidak sabar dalam mendampingi anak saat belajar dirumah, kesulitan orang tua dalam mengoperasikan gadget, dan kendala terkait jangkauan layanan internet, oleh karena itu perubahan membutuhkan waktu untuk bisa berjalan optimal.

Melansir laman ruang guru PAUD Kementrian Pendidikan dan Kebudayaan (Kemendikbud), Jumat (17/7/2020) terdapat pengalaman orang tua yang dibagikan dalam sesi Webinar Orang Tua berbagi "Rumahku Sekolahku”. Salah satu orang tua siswa PAUD Terpadu Anak Saleh, Malang, Jawa Timur, Wempi Maron menjelaskan beberapa masalah dalam pelaksanaan pembelajaran yang dilakukan dari rumah tersebut, antara lain ketidaksiapan menerima perubahan, perilaku anak yang berbeda (moody), komunikasi dengan guru yang terhambat, dan rendahnya tingkat ketersediaan perangkat teknologi informasi (edukasi.kompas.com).

Secara garis besar, hasil penelitian ini tidak jauh berbeda dengan masalah dalam pelaksanaan pembelajaran yang dilakukan dari rumah yang dijelaskan diatas. Secara spesifik, kendala yang dialami orang tua dalam mendampingi anak belajar dirumah di masa pandemi Covid-19 akan dijabarkan dibawah ini.

\section{Kurangnya Pemahaman Materi Oleh Orang Tua}

Hasil penelitian dilapangan menunjukkan bahwa pemahaman meteri oleh orang tua dalam mendampingi anak belajar dirumah dimasa pandemi ini menjadi kendala dalam pelaksanaannya, ditunjukkan dengan hasil wawancara kepada orang tua yang menyatakan bahwa menyampaikan ilmu kepada anak usia dini tidaklah mudah dan membutuhkan latihan khusus. Hal ini sejalan dengan penelitian sebelumnya, yang menyatakan bahwa selama pembelajaran dirumah atau daring, banyak orang tua yang kurang dalam memahami materi yang diberikan oleh pihak sekolah atau guru orang, orang tua menganggap tugas yang diberikan terlihat sulit sehingga mereka sulit untuk menyampaikannya kepada anak (Cahyati \& Kusumah, 2020) 
Pemahaman materi yang luas yang dimiliki oleh orang tua sangat bermanfaat dalam membantu anak belajar dirumah. Orang tua membantu anak belajar dirumah berdasarkan kegiatan yang ada disekolah, seperti membacakan buku cerita yang mendidik dan membantu anak mengerjakan tugas-tugas dari sekolah (Diadha, 2020). Pembelajaran tidak bisa maksimal jika orang tua belum sepenuhnya memahami materi yang diberikan oleh guru untuk diajarkan kepada anak, seperti yang diungkapkan oleh penelitian sebelumnya bahwa bahwa orang tua harus benar benar menguasai materi pembelajaran yang diberikan oleh guru agar terlaksananya pendidikan dirumah menjadi sukses (Irma et al., 2019). Hal ini sependapat dengan penelitian yang dilakukan oleh Irhamnna yang menyatakan bahwa peran orang tua dalam memahami materi yang di berikan dari pihak sekolah sangat penting dalam meningkatkan kualitas pembelajaran anak (Irhamna, 2016.).

... ibu guru disekolah meminta orang tua untuk secara konsisten membiasakan anak untuk selalu berdoa sebelum dan sesudah belajar dirumah, namun saya sendiri tidak hafal bacaan doa sebelum dan sesudah belajar, ini menjadi hal yang sulit... (kutipan wawancara dengan ibu OZ)

... saya tidak mampu membaca huruf hijayyah, bagaimana bisa saya mengajarkannya kepada anak saya dirumah ?... (kutipan wawancara dengan ibu $N L$ )

... saya bisa membaca, namun mengajarkan anak untuk belajar mengeja kata sangatlah sulit, hal ini butuh teknik tertentu...(kutipan wawancara dengan ibu NS)

... saya perlu berdiskusi langsung dengan guru terkait pemberian materi ajar untuk anak saya, karena saya belum memahaminya... (kutipan wawancara dengan ibu WN)

Kendala kurangnya pemahaman materi oleh orang tua disebut juga kendala pedagogi, bentuk kendalanya meliputi, belum pernah mendapatkan pelatihan, belum berpengalaman, dan belum mendapatkan pendampingan (Muhdi, 2021). Kendala kendala yang telah disebutkan terkait kurangnya pemahaman materi oleh orang tua bisa diatasi atau diminimalisir dengan adanya musyawarah antara orang tua dan guru, supaya guru bisa memberikan alternatif lain kepada orang tua. Masukan- masukan dari guru sangat bermanfaat untuk mengatasi rasa sulit yang dialami oleh orang tua (Irhamna, 2016).

\section{Kesulitan Dalam Menumbuhkan Minat Belajar Anak}

Menumbuhkan minat belajar anak menjadi juga menjadi kendala yang dirasakan oleh orang tua selama mendampingi anak belajar dirumah dimasa pandemi Covid-19. Hal ini tentu menjadi hambatan yang berarti, mengingat bahwa membangun motivasi anak adalah cara yang ampuh dalam membentuk hasil akademis anak yang bagus (Master \& Walton, 2013).

Mengungkapkan minat secara keseluruhan memberikan kekuatan untuk belajar, oleh sebab itu hal pertama yang penting dalam sebuah pembelajaran adalah menumbuhkan minat untuk belajar (Hurlock, 1978). Minat juga bisa diartikan sebagai suatu kecenderungan untuk memberikan perhatian dan bertindak terhadap seseorang, aktivitas atau situasi yang menjadi objek dari minat tersebut disertai dengan perasaan senang (Nofita, 2012). Memperhatikan pendapat tersebut dapat disimpulkan bahwa menumbuhkan minat anak untuk belajar sangat berperan penting dalam melaksanaan aktivitas belajar atau kegiatan pembelajaran. Namun yang dihadapi orang tua dalam mendampingi anak belajar di rumah di masa pandemi Covid-19 berbeda dari yang diharapkan.

... anak lebih suka belajar dengan gurunya disekolah sehingga tidak tertarik ketika saya yang membimbing, anak menjadi tidak fokus karena minatnya dalam belajar sangatlah kurang ... (kutipan wawancara dengan ibu AP) 
... setiap akan belajar bersama saya anak selalu mengeluh rindu dengan teman- temannya, ingin belajar jika bersama dengan teman- temannya dan rewel ketika pembelajaran akan dimulai sehingga saya hanya mampu meminta anak untuk lebih bersabar menunggu pandemi ini segera berakhir dan bisa kembali belajar disekolah dengan teman- temannya... (kutipan wawancara dengan ibu RS)

... anak terlihat malas ketika memulai kegiatan dengan orang tuanya sendiri.... (kutipan wawancara dengan ibu NV)

... atensi anak belajar dirumah tidak bisa lama, paling hanya 30 menit lalu anak memilih kegiatan yang lain seperti menonton TV... (kutipan wawancara dengan ibu AR)

Dalam proses pembelajaran di rumah, pastilah anak mengalami kecemasan, stress, sedih, bosan, jenuh, dan perasaan lainnya sehingga menurunkan minat belajar anak. Bagi anak seperti ini disinilah peran orang tua sangat dibutuhkan agar anak memiliki selfregulating sehingga mampu mengajarkan dirinya dalam upaya memberikan penguatan secara internal. Bila anak telah memulai membangun penguatan di dalam dirinya sesuai dengan tugas-tugas pembelajaran yang dijalaninya hal ini akan memberikan dampak yang signifikan bagi diri anak. (Subarto, 2020).

Strategi orang tua mengajarkan dan membangun regulasi diri, kepada anak untuk mengembangkan perilaku yang dilepaskan guna memiliki kemampuan mengatur dan merencanakan proses belajarnya sendiri setiap hari di rumah, antara lain yang dapat dilakukan adalah, mendiskusikan tentang beberapa aturan di dalam rumah, memberikan arah kepada anak tentang perilaku yang sewajarnya, contohnya adalah agar anak mendapatkan panduan untuk mencapai prestasi, menyampaikan cara yang tidak rumit kepada anak untuk memecahkan masalah yang berkaitan dengan kemampuan menjaga hubungan interpersonal dengan guru dan teman kelasnya selama di rumah, jika anak menunjukkan perilaku yang emosional, tunjukkan cara mengatasinya dan juga jelaskanlah akibat dari perilaku tersebut, jadilah sahabat atapun teman dalam berbagi tugas yang berkaitan dengan regulasi diri (contohnya sebagai teman berpikir dalam menyelesaikan tugas dan menjadi teman untuk bertanya), dan ini harus menjadi proses yang konsisten, mempersiapkan dan menunjukan strategi yang nyata kepada anak dalam usaha mempertahankan kemampuan belajarnya (contohnya mempersiapkan dan menjadwalkan kegiatan belajar anak secara terperinci agar mudah diikuti), mempersiapkan petunjuk bagaimana sebaiknya belajar yang efektif (contohnya memberi anak pertanyaan lalu kemudian meminta anak untuk memberi jawaban secara lengkap dengan cara membaca buku-buku yang ada di rumah), berikanlah kesempatan kepada anak untuk mengerjakan tugas secara mandiri yang rumit dan tentu saja orang tua perlu mempersiapkan petunjuk yang dapat dijadikan acuan untuk anak, terutama yang belum memiliki kemampuan untuk mengatur kegiatan belajar secara mandiri sebelumnya (Subarto, 2020)

\section{Kesulitan Dalam Mengoperasikan Gadget}

Kesulitan dalam mengoperasikan gadget juga menjadi kendala yang dihadapi orang tua dalam mendampingi anak belajar dirumah dimasa pandemi Covid-19. Hal ini sejalan dengan penelitian lain yang menyatakan bahwa dalam pembelajaran daring, tidak semua orang tua mampu mengoperasikan gadget karena ada beberapa orang tua yang keadaanya masih belum melek teknologi (Lestari \& Gunawan, 2020). Penguasaan teknologi yang rendah oleh orang tua saat pembelajaran daring juga disebutkan dalam penelitian yang dilakukan oleh Karnawati \& Mardiharto (2020). Mereka berpendapat bahwa hal ini merupakan kendala yang paling sering ditemui dalam pembelajaran daring. 
... guru menggunakan aplikasi zoom yang belum pernah saya tahu sebelumnya, sehingga saya juga kesulitan dalam penggunaannya, terlebih lagi kita juga tidak diberikan pedoman mengenai penggunaan zoom dari pihak sekolah... (kutipan wawancara dengan ibu BL)

... saya membeli HP ketika dibutuhkan untuk pembelajaran daring sehingga saya baru belajar dari awal mengenai cara menggunkan HP .... (kutipan wawancara dengan ibu AT)

... handphone yang saya gunakan adalah handphone model lama, sehingga saya kesulitan dalam mengikuti perkembangan pembelajaran daring, ...(kutipan wawancara dengan ibu OK)

Mengingat bahwa didalam pembelajaran daring, tidak semua orang tua mampu megoperasikan gadget, penting untuk diperhatikan bahwa komunikasi antara orang tua dan guru sangat dibutuhkan dalam hal ini (Herliandry et al., 2020) guru bisa meminimalkan tingkat kesulitan penggunaan gadget terhadap orang tua yang memiliki keluhan terhadap pengoperasian gadget. Guru bisa memberikan pekerjaan siswa melalui pesan singkat kepada orang tua dan membantu anak untuk menyelesaikannya.

\section{Tidak Memiliki Cukup Waktu Untuk Mendampingi Anak Belajar Dirumah Karena Harus Bekerja}

Orang tua tidak memiliki cukup waktu untuk menemani anak belajar dirumah karena harus bekerja menjadi masalah lain dimasa pandemic Covid-19 ini. Peran orang tua sangatlah penting dalam pelaksanaan belajar dirumah di masa pandemi Covid-19, sebab orang tua adalah pendidik yang pertama bagi anak dalam pendidikan keluarga, maka dari itu, orang tua harus selalu berupaya semaksimal mungkin untuk membimbing anak ketika belajar dirumah (Irhamnna, 2016.). Berdasarkan hasil penelitian, kendala yang dihadapi orang tua dalam membina anak adalah terkadang kurangnya waktu yang dimiliki orang akibat sibuk bekerja di luar.

... saya dan suami harus bekerja dan tidak memiliki waktu untuk menemani anak belajar di rumah. Biasanya sikecil saya titipkan di TPA dan saya jemput jam 16.00 ketika saya pulang bekerja. Sikecil sekarang saya titipkan tempat eyang, sehingga saya hanya mampu mendampingi anak belajar dirumah ketika pulang kerja... (kutipan wawancara dengan ibu $\mathrm{OK})$

... saya terpaksa keluar dari pekerjaan saya karena harus fokus untuk menemani anak saya belajar dirumah ... (kutipan wawancara dengan ibu WN)

... saya bekerja sebagi pembantu rumah tangga ditempat tetangga, oleh karena itu mendampingi anak belajar dari rumah bagi saya sedikit berat, saya hanya mampu meminta izin kepada pemilik rumah tempat saya bekerja selama 30 menit untuk mendampingi anak saya belajar dirumah (kutipan wawancara dengan ibu AR)

... karena saya adalah ibu yang bekerja, maka saya hanya dapat menemani anak belajar dirumah ketika selesai bekerja... (kutipan wawancara dengan ibu EP)

Dengan keterbatasan waktu yang dimiliki oleh orang tua untuk mendampingi anak belajar dirumah, seharusnya tidak bisa menjadi penghalang momentum keluarga dan juga menjadi ekspetasi kita semua sehubung dengan surat edaran nomor 4 tahun 2020 tentang pelaksanaan kebijakan pendidikan dalam masa darurat penyebaran corona virus disease (Covid-19). Dengan adanya sinergisitas dari semua pihak bagaimana upaya menjadikan setiap orang sebagai pendidik dan sekaligus sebagai peserta didik, maka tidak mustahil 
bahwa momen "belajar dari rumah" ini akan berjalan dengan sukses walaupun terkendala oleh keterbatasan waktu (Subarto, 2020)

\section{Orang Tua Tidak Sabar Dalam Mendampingi Anak Belajar Dirumah}

Banyak orang tua dalam menemani belajar anak dirumah kurang sabar sehingga muncul kekesalan dan melampiaskannya pada anak. Sejatinya orang tua harus menjadi figur dalam memberi kesabaran pada anak, hal lain menunjukkan bahwa ternyata orang tua juga sudah merasa jenuh dengan pembelajaran yang dilakukan dirumah serta WFH yang di terapkan hal itu memicu ketidaksabaran orang tua dalam menemani anak belajar dan bermain (Tabiin, 2020). Ketidaksabaran adalah salah satu kesalahan dalam mendidik anak, dan tenyata masih banyak orang tua yang kurang sabar dalam mendidik anak, hal ini tentunya sangat disayangkan karena orang tua mempunyai kewajiban untuk membentuk, mengarahkan, membmbing, dan mendidik anak dengan penuh kesabaran (Iriani, 2014).

... anak saya selalu marah- marah ketika tidak mampu menyelesaikan pekerjaan dengan benar, sehingga saya juga mudah untuk marah balik kepada anak saya... (kutipan wawancara dengan ibu RS)

... anak saya lebih suka dibimbing oleh guru disekolah dari pada saya, orang tuanya. Padahal ini merupakan tanggung jawab saya, namun sering kali saya tidak sabar ketika anak saya menangis dan marah saat ia ingin dibimbing oleh guru disekolah... (kutipan wawancara dengan ibu AT)

.... Hal yang sebenarnya saya sayngkan adalah ketika anak tidak kunjung memahami apa yang saya sampaikan saat mendampingi anak belajar dirumah, maka saya akan lekas memarahinya... (kutipan wawancara dengan ibu NL)

... membimbing seorang anak kecil layaknya guru sangatlah tidak mudah, dan terkadang orang tua tidak sabar menghadapi kelakuan anak dan mulai meneriakinya (kutipan wawancara dengan ibu NV)

Sejatinya orang tua harus mengetahui bahwa kesejahteraan psikologis anak, dalam arti anak tidak menjadi cemas atau stres dalam situasi baru (Tabiin, 2020). Dalam hal ini orang tua harus mengambil sikap memformulasikan penanganan tantrum pada anak yang diakibatkan kejenuhan saat belajar dirumah, yaitu orang tua mengenali pola tantrum anak serta meminimalisir terjadinya tantrum pada anak.

\section{Kendala Terkait Jangkauan Layanan Internet}

Letak kepulauan Indonesia yang beragam menyebabkan tidak semua wilayah terjangkau oleh layanan internet dan sebaran jaringan internet yang lamban sewaktu-waktu (Ratu et al., 2020). Hal negatif lain mengenai layanan internet yaitu memungkinkan berpengaruh pada kesehatan peserta didik. Kendala lain yang ditemukan yaitu kemampuan orang tua untuk memberikan fasilitas pendidikan online seperti penggunaan jaringan internet yang membutuhkan biaya yang tidak sedikit (Jones \& Sharma, 2019).

Kondisi tersebut tampaknya berbeda dengan di Cina yang telah sanggup menyediakan infrastruktur pendukung pembelajaran daring di sekolah dan universitas dengan lebih baik. Sejak beberapa dekade terakhir Pemerintah Cina telah membangun sejumlah proyek nasional untuk menyiapkan infrastruktur pembelajaran daring di sekolah bahkan membuat proyek sekolah online (Wang \& Chen, 2009).

... dilingkungan tempat tinggal saya, jangkauan layanan internet sangat lemah, sehingga saya perlu untuk menuju ketempat yang sinyal internetnya lebih bagus agar komunikasi 
pembelajaran daring tetap lancar, namun hal ini sangat merepotkan... (kutipan wawancara dengan ibu $B L$ )

.... Saya tidak pernah mengikuti pembelajaran via zoom karena keterbatasan sinyal, namun guru saya minta untuk menjelaskan pekerjaan anak via chat, hal ini juga mampu membuat biaya untuk membeli kuota juga semakin sedikit... (kutipan wawancara dengan ibu EP)

... ditempat saya tinggal sangat susah untuk mencari sinyal ketika pembelajaran daring dilasanakan, biaya untuk membeli paket kuota juga mahal untuk provider yang sinyalnya kuat ... (kutipan wawancara dengan ibu OZ)

Permasalahan-permasalahan yang disebutkan diatas tentu harus tetap di evaluasi supaya anak-anak dapat memperoleh pembelajaran yang lebih baik. Kuncinya adalah untuk melakukan pembelajaran online sesuai dengan kondisi setempat (Zhang et al.,2020.), apalagi di negara Indonesia yang masih banyak daerah- daerah dengan minimnya jangkauan internet.

Kendala- kendala yang dihadapi oleh orang tua dalam mendampingi anak belajar dirumah dimasa pandemi Covid-19 seperti yang telah dijabarkan, yaitu kurangnya pemahaman materi oleh orang tua, kesulitan orang tua dalam menumbuhkan minat belajar anak, tidak memiliki cukup waktu untuk mendampingi anak karena harus bekerja, orang tua tidak sabar dalam mendampingi anak saat belajar dirumah, kesulitan orang tua dalam mengoperasikan gadget, dan kendala terkait jangkauan layanan internet sangat diharapkan kedepannya hal ini tidak lagi menjadi kendala dalam pembelajaran dirumah untuk anak supaya anak mampu mendapatkan layanan pembelajaran yang optimal, karena layanan yang baik dan optimal untuk anak dalam belajar adalah kunci utama dalam suksesnya tujuan pembelajaran (Palusci \& Fischer, 2010)

\section{SIMPULAN}

Secara umum kendala- kendala orang tua dalam mendampingi anak belajar di rumah di masa pandemi Covid-19 adalah kurangnya pemahaman materi oleh orang tua, kesulitan orang tua dalam menumbuhkan minat belajar anak, tidak memiliki cukup waktu untuk mendampingi anak karena harus bekerja, orang tua tidak sabar dalam mendampingi anak saat belajar dirumah, kesulitan orang tua dalam mengoperasikan gadget, dan kendala terkait jangkauan layanan internet.

\section{UCAPAN TERIMAKASIH}

Ucapan terima kasih disampaikan kepada seluruh responden dalam penelitian ini juga kepada Prodi Pascasarjana Pendidikan Anak Usia Dini Fakultas Ilmu Pendidikan Universitas Yogyakarta, Indonesia atas kesempatan mengekplorasi dunia pendidikan anak usia dini di perguruan tinggi.

\section{DAFTAR PUSTAKA}

Albertus, A. (2020, 07 22). edukasi.kompas.com. Diambil kembali dari https:/ / edukasi.kompas.com/read/2020/07/22/090351771/ini-kendala-orangtuadampingi-anak-paud-belajar-di-rumah?page=all\#page 2

Cahyati, N., \& Kusumah, R. (2020). Peran Orang Tua Dalam Menerapkan Pembelajaran Di Rumah. Jurnal Golden Age, Universitas Hamzanwadi, Vol. 04 No. 1, Juni 2020, Hal. 152159.

Euis, K., Alfeani , D. K., \& Andriani , F. (2020). Analisis Peran Orang Tua dalam Mendampingi Anak di Masa Pandemi Covid-19. Jurnal Obsesi: Jurnal Pendidikan Anak Usia Dini, 354-365 DOI: 10.31004/OBSESI.V51I.54. 
DOI: 10.31004/obsesi.v5i1.705

Fajriani, R. N. (2020, 08 08-08-2020). Diambil kembali dari www.pikiran-rakyat.com: https://www.pikiran-rakyat.com/internasional/pr-01649717/update-virus-coronadi-dunia-4-agustus-2020-catat-lebih-dari-18-juta-kasus-positif-covid-19?page=3

Heriyanto, H. (2018). Thematic Aanalysis sebagai Metode Menganalisa Data Untuk Penelitian Kualitatif. Anuva, https:/ / doi.org/10.14710/anuva.2.3.317-324.

Herliandry, L., Nurhasanah, Maria, E., \& Kuswanto, H. (2020). Pembelajaran Pada Mas pandemi Covid 19. Jurnal Teknologi Pendidikan, Vol.22 No. 1 DOI: https://doi.org/10.21009/jtp.v22i1.15286.

Hurlock, E. (1978). Perkembangan Anak. Jakarta: Erlangga.

Irhamna. (2016). Analisis Kendala yang Dihadapi Orang Tua dalam Menanamkan Akhlak dan Kedisiplinan Belajar Siswa Madrasah Darussalam Kota Bengkulu. Pembelajaran Alquran Hadis di Man Pagar Alam, 57-65.

Iriani, D. (2014). 101 Kesalahan Dalam Mendidik Anak. Jakarta : PT Elex Media Komputindo .

Irma, C., Nisa, K., \& Sururiyah, S. (2019). Keterlibatan Orang Tua dalam Pendidikan Anak Usia Dini Ddi TK Masyitoh Purworejo. Jurnal Obsesi : Jurnal Pendidikan Anak Usia Dini, doi: https://doi.org/10.31004/obsesi.v31i.152.

Jones, K., \& Sharma, R. (2019). Imagining A Future For Online Learning. New York.

Karnawati, \& Mardiharto. (2020). Sekolah Minggu Masa Pandemi Covid-19: Kendala, Solusi, Proyeksi. Jurnal STT Simpson, 13-24 doi: 10.46445/djce.vlil.291.

Khasanah, Pramudibyo, \& Widuroyekti. (2020). Pendidikan Dimasa Pandemi Covid-19. Jurnal Sinestesia, 10(1), 41-48.

Lee, A. (2020). Wuhan Novel Corona Virus (Covid-19): Why Global Control is Challenging? Public Health, 179, A1-A2. DOI: 10.1016/J.PUHE.2020.02.001.

Lestari, A., \& Gunawan. (2020). The Impact of Covid-19 Pandemic on Learning Implementation of Primary and Secondary School Levels. Indonesian Journal of Elementary and Childhood Education, Vol. 1 No. 2 58-63.

Master, A., \& Walton, M. G. (2012). Minimal Groups Increase Young Children's Motivation and Learning on Group-Relevant Tasks. Wiley Online Library, https://doi.org/10.1111/j.1467-8624.2012.01867.x.

Muhdi, \& Nurkolis. (2020). Keekfektivan Kebijaan E- Learning Berbasis Sosial Media pada PAUD di Masa Pndemi Covid-19. Jurnal Obsesi: Jurnal Pendidikan Anak Usia Dini, DOI: $10.31004 /$ obsesi.v5i1.535.

Nawawi, H. (2003). Manajemen SDM Untuk Bisnis yang Kompetitif. Yogyakarta: Gadjah Mada University Press.

Nofita, A. (2013). Hambatan - Hambatan Warga Belajar Dalam Proses Pembelajaran Program Paket C Di Kecamatan Pancung Soal Kabupaten Pesisir Selatan. Program Sutdi Luar Sekolah.

Obiakor, T., \& Adeniran, A. (2020). Covid-19: Impending Situation Threatens To Deepen Nigeria' S Education Crisis. Center For The Study Of The Economies Of Africa.

Palusci, S., \& Doom, J. (2020). Stress and Parenting during the Global COVID-19 Pandemic. PsyArXiv Preprints, 1-41. DOI :10.31234/osf.io/ucezm.

Prabhawani, S. (2016). Pelibatan Orang Tua Dalam Program Sekolah. FKIP UNY, 1-202.

Putra, R., \& Irwansyah, I. (2020). Media Komunikasi Digital, Efektif namun Tidak Efisien, Studi Media Richness Theory dalam Pembelajran Jarak Jauh Berbasis Teknologi di Masa Pandemi. Jurnal Ilmu Sosial dan Politik, 1(2), 1-13.

Rahminur, D. (2015). Keterlibatan Orang Tua dalam Pendidikan Anak Usia Dini di Taman Kanak-Kanak . Edusentris: Jurnal Ilmu Pendidikan dan Pengajaran, Vol.2, No.1.

Rahmita, M., Yulianingsih , I., Tarihoran, T., \& Bahfen, M. (2020). Kesiapan Ibu Bermain Bersama Anak Selama Pandemi " Dirumah Saja". Jurnal Obsesi: Jurnal Pendidikan Anak Usia Dini, 476-489 DOI: 10.31004/obsesi.v5i1.548. 
Rohayani, F. (2020). Menjawab Problematika Yang Dihadapi Anak Usia Dini di Masa Pandemi. Qawwam: Journal For Gender Mainstreaming, Vol. 14, hal. 29-50, doi: 10.20414/Qawwam.v14i1.2310.

Sari, Mutmainah, R. N., Yulianingsih, I., \& Astari, T. (2020). Kesiapan Ibu Bermain Bersama Anak selama Pandemi Covid-19. Jurnal Obsesi: Jurnal Pendidikan Anak Usia Dini, 476489 doi: 10.31004/obsesi.v5i1.548.

Satrianingrum, A., \& Prasetyo, I. (2020). Persepsi Guru Dampak Pndemi Covid-19 Terhadap Pelaksanaan Pembelajaran Daring di PAUD. Jurnal Obsesi: Jurnal Pendidikan Anak Usia Dini, 633-640 doi: 10..31004/obsesi.v5i1.574.

Subarto. (2020). Momentum Keluarga Mengembangkan Kemampuan Belajar Peserta Didik Di Tengah Wabah Pandemi Covid-19 . Universitas Pamulang, DOI: 10.15408/41i.15838.

Sun, L., Tang, Y., \& Zuo, w. (2020). Corona Virus Pushes Education Online. Nature Materials, 687-687. Doi: https:// doi.org/10.1038/s41563-202-0678-8.

Tabiin. (2020). Problematika Stay At Home Pada Anak Usia Dini Ditengah Pandemi. Jurnal Golden Age, Vol. 04 No. 1 Hal 190-200 E-ISSN: 2549-7367.

W, Y., Wang, Y., \& Wang, C. (2020). Suspending Classes Without Stopping Learning : China ' $\mathrm{s}$ Education Emergency Management Policy in the Covid-19 Outbreak. Risk and Financial Management, 13(55), 1-6. https:/ / doi.org/doi:10.3390/jrfm13030055.

Wang, Q., Zhu, Q., Chen , L., \& Yan , H. (2009). E-learning in China . Campus-Wide Information Systems, 26, n.2. https:// doi.org/10.1108/10650740910946783.

Yin, R. (2003). Case Study Research : Design and Method. Open Journal of Social Sciences, 6890. 